\title{
Derleme https://doi.org/10.33484/sinopfbd.524412 \\ Gıda Katkı Maddelerinin Yenilebilir Film ve Kaplamalar Kullanılarak Taşınmasının Günümüzde ve Gelecekteki Uygulama Potansiyeli
}

\author{
Bahar DEMIRCAN, Özgül ÖZDESTAN OCAK* \\ Ege Üniversitesi, Mühendislik Fakültesi, Gıda Mühendisliği Bölümü, 35100 Bornova/İzmir
}

$\ddot{\mathbf{O z}}$

Günümüzde tüketicilerin güvenli gıdalara taleplerinin artması doğrultusunda, gıda üretim ve işleme endüstrisi ürünlerde daha uzun raf ömrü sağlama yönünde yeni stratejiler geliştirmektedir. Birçok işlenmiş gıda, proses sonrası yüzey kontaminasyonuna maruz kaldığından ürünlerin raf ömrü kısalmaktadır. Gıda endüstrisi potansiyel olarak ambalajlama işlevini yerine getirebilecek olan yenilebilir film ve kaplamalar üzerinde çalışmalara odaklanmıştır. Yenilebilir film ve kaplamaların bir ambalaj malzemesi olarak kullanımı üzerine odaklanan araştırmalar, bu sistemlerin gıda kalitesini, gıda güvenliğini ve raf ömrünü arttırma potansiyeli nedeniyle günden güne artmaktadır. Yenilebilir film ve kaplamaların işlevsellikleri film materyallerinin yapı ve doğasına bağlıdır. Film oluşturucu madde veya aktif katkı maddesi seçimi gıda ürününün yapısına, uygulanacak işlemlere ve amaca uygun olarak yapılmalıdır. $\mathrm{Bu}$ nedenle üründe arzu edilen özellikler, hidrokolloid ve lipitlerin kombinasyonlarından oluşan kompozit filmler ile elde edilebilir. $\mathrm{Bu}$ sistemler kütle difüzyonuna karşı bir engel oluşturmasının yanı sıra antioksidanlar, vitaminler, renklendiriciler gibi çok çeşitli gıda katkı maddeleri için de taşıyıcı olarak kullanılabilirler. Bu katkıların yapılara eklenmesi başta mikrobiyal bozulma olmak üzere diğer bozulma etkenlerini ortadan kaldırarak gidaların daha uzun süre güvenli bir şekilde depolanmasını sağlayabilir. Bu derlemede, geliştirilen çeşitli protein, polisakkarit ve lipit bazlı yenilebilir film ve kaplamalar kullanılarak, bu filmlere dahil edilmiş veya potansiyel olarak dahil edilebilecek olan çeşitli gıda katkı maddelerinin taşınması ele alınmıştır.

Anahtar kelimeler: Yenilebilir film ve kaplamalar, gida katkı maddeleri, gida kalitesi, raf ömrü, koruyucu gıda sistemleri

\section{Current and Future Application Potential of Transferring Food Additives Using Edible Films and Coatings}

\begin{abstract}
New strategies have being developed in the food production and processing industry to ensure longer shelf life in the products and to satisfy the increasing demand of consumers for safe foods. The shelf life of the products is reduced because many processed foods are subjected to surface contamination after the process. The food industry has focused on studies on edible films and coatings that could potentially fulfill the packaging function. The number of research focusing on the use of edible films and coatings as a packaging material increases due to the potential to increase food quality, food safety, and shelf life of these systems. The functionality
\end{abstract}

\footnotetext{
${ }^{*}$ Sorumlu Yazar: : ORCID ID: orcid.org/ 0000-0003-0967-8865

e-mail: ozgul.ozdestan@ege.edu.tr
}

Received: 08.02.2019

Accepted: 03.07.2019 
of edible films and coatings depends on the nature and structure of film materials. The choice of film-forming agent or active ingredient should be made considering the structure of the food product, the procedures to be applied, and the purpose of usage. Therefore, the desired properties in the product can be obtained by composite films consisting of hydrocolloids and combinations of lipids. These systems can be used as carriers for a wide range of food additives, such as antioxidants, vitamins, colorants, as well as being a barrier against mass diffusion. Addition of these additives to the structures can eliminate the other deterioration factors, especially microbial deterioration, and can ensure the safe storage of foods for a longer period. In this review, the use of a variety of protein, polysaccharide, and lipid based edible films and coatings to develop a variety of food additives included or potentially incorporated into these films has been discussed.

Keywords: Edible film and coatings, food additives, food quality, shelf life, protective food systems

\section{Giriş}

Yenilebilir film ve kaplamaların fonksiyonel etkinliği, film bileşenlerinin yapısına bağlıdır. Bir film oluşturucu madde ve/veya aktif katkı maddesi seçimi, hedeflenen etkiye, gida ürününün yapısına ve uygulama şekline bağlıdır. Örneğin lipitler veya reçineler, mumlar ve bazı çözünmeyen proteinler gibi hidrofobik maddeler nem transferini geciktirmek için kullanılan en etkili materyallerdir. Aksine, polisakkaritler ve proteinler gibi suda çözünür hidrokolloidler, nem transferine karşı engel oluşturan materyaller değildirler. Ayrıca, hidrokolloidler genellikle yenilebilir film ve kaplamalara, lipitlerden ve hidrofobik maddelerden daha iyi mekanik özellikler sağlamaktadırlar. Bununla birlikte gazlara karşı geçirgenlikleri çoğu zaman plastik filmlerden daha düşüktür. Ayrıca hidrokolloidler genellikle yenilebilir film ve kaplamalara lipitler ve hidrofobik maddelerden daha iyi mekanik özellikler sağlamaktadırlar. Bu nedenle, arzu edilen özelliklerin kompozisyonları, kompozit filmler oluşturmak için hidrokolloidlerin ve lipitlerin birlikte kullanımıyla elde edilmektedir. Film oluşturucu maddeler, özellikle proteinler, kompozit emülsiyon bazlı yenilebilir filmlerde hidrofobik partikül dağılımını arttırmak için film direnci ve elastikiyetini arttırmak için plastikleştiriciler gibi film katk1 maddelerini veya emülsiyonlaştırıcıları gerektirmektedir [1].

Yenilebilir film ve kaplamaların önemli işlevlerinden biri, gıdaların raf ömrünü arttırmak için antimikrobiyal ve antifungal ajanların taşıyıcıları olarak kullanılmasıdır. Ayrıca, işlenmiş gıda ürünlerinin besin değerini arttırmak için besin taşıyıcıları olarak da kullanılabilirler. Gıdalarda aktif taşıyıcı sistemler olarak yenilebilir film ve kaplamaların kullanımı 
ISSN: 2536-4383

göreceli olarak yeni bir kavramdır, ancak bu işlev farmasötikler üzerinde geniş çapta çalışılmış ve kullanılmıştır [2].

Kaplamaların ve filmlerin ana bileşenleri olan biyopolimerler, yönetmelikler kapsamında katkı maddesi olarak kabul edilmektedir. Ayrıca söz konusu biyopolimerler, plastikleştiriciler, yapıştırma maddeleri, emülgatörler, aktif veya fonksiyonel katkı maddeleri gibi daha küçük molekülleri de taşıyabilmektedirler. Bununla birlikte, bu bileşenler esas işlevleri olan gıda-hava ara yüzünde bir su bariyeri görevi de görmektedirler. Yenilebilir filmler ve kaplamalar için uygulamaların çeşitliliği, on yedinci yüzyıldan beri literatürde yer almaktadır. Gıdalarda kullanım amaçlı geliştirilen yenilebilir filmler hakkındaki patentler 1942 yılından itibaren bildirilmektedir. Geçmişten günümüze ürünlerin raf ömrünü uzatmak, tazeliğini korumak, dehidrasyonu önlemek, görünüş özelliklerini iyileştirmek ve parlaklık kaybını önlemek için yenilebilir kaplamalar kullanılmıştır [2].

Gıda ve İlaç İdaresi (FDA), bir gıda katk1 maddesini, "kullanım amacı ile sonuçlanan veya doğrudan veya dolaylı olarak bir bileșen haline gelmesi veya herhangi bir gidanın karakteristiklerini etkilemesi ile sonuçlanması beklenen bir madde" olarak tanımlamaktadır [3]. Aynı kurum, bir antimikrobiyali ise “mikroorganizmaları öldüren veya bunların çoğalmasını önleyen veya kısıtlayan bir bileşik veya madde ve bir üründe bozulmayı önlemek veya bulaşan mikroorganizmaların büyümesini önlemek için yeterli bir konsantrasyonda bulunan ancak içinde bulunduğu ürünün etkilerine katkıda bulunmayan madde" olarak tanımlamaktadır [4].

$\mathrm{Bu}$ derlemenin amacı yenilebilir film ve kaplamalar kullanılarak gida katk1 maddelerinin, özellikle antimikrobiyallerin ve antioksidanların taşınmasının günümüzde ve gelecekteki uygulama potansiyeli hakkında bilgi vermektir.

\section{Yenilebilir Film ve Kaplamalara Katkı} Maddelerinin Eklenmesi

Gıda sistemlerinde yenilebilir filmlerin kullanımı biraz yeni olsa da yüzlerce yıl önce gida ürünleri film ve kaplamalarla kaplanmaktaydı. Balmumu, on ikinci ve on üçüncü yüzyıldan beri Çin'deki turunçgillerin dehidrasyonunu geciktirmek için kullanılmıştır. Et ürünlerinde büzüşmeyi önlemek için lipit bazlı kaplamaların uygulanması ise on altınc1 yüzyıldan beri geleneksel bir uygulama olmuştur, ancak sonraları et ve diğer gida maddeleri jelatin filmlerle kaplanarak korunmuştur. Kaynatılmış soya 
sütünde oluşan zar yapıdan elde edilen ve protein yapılı yenilebilir bir film olan Yuba, geleneksel olarak on beşinci yüzyıldan beri gıdaların korunmasına yardımcı olmak için Asya'da kullanılmıştır. On dokuzuncu yüzyılda sakkaroz çözeltisi, depolama sırasında oksidasyon ve ransisiteyi önlemek için findık ve bademde yenilebilir koruyucu bir kaplama olarak uygulanmıştır [5].

1930'lardan beri yenilebilir film ve kaplama teknolojisindeki en önemli gelişmelerden biri, mum, yağ ve sudan yapılan bir emülsiyonun kullanımıdır. Bu tür emülsiyonlar, meyvelerin görünüşünü (parlaklık ve renk) iyileştirmek, yumuşamayı önlemek, olgunlaşmayı kontrol etmek ve nem kaybını geciktirmek için kullanılmaktadır. Depolama boyunca et kalitesini iyileştirmek için aljinatlar, karragenanlar, selüloz eterleri, pektin ve nişasta türevleri dahil olmak üzere çeşitli yenilebilir polisakkarit kaplamalar kullanılmıştır. Son 40 yılda, çok sayıda çalışmada yenilebilir film ve kaplamaların formülasyonu, uygulanmasi ve karakterizasyonu araştırılmıştır; $\mathrm{Bu}$ araştırmaların kanıtları hem bilimsel hem de patent literatüründe bulunmaktadır [1].

\section{Gıda Katkı Maddeleri}

\section{Antimikrobiyaller}

Birçok gıda ürününde bozulmanın esas nedeni yüzeydeki mikrobiyal çoğalmadır. Su aktivitesinin (aw) azaltılması ve nem bariyeri özelliğine sahip ambalaj kullanılması, gıda ürünlerinde bozulmayı önlemek için yaygın olarak kullanılan yöntemlerdir. Bununla birlikte, sıcaklık değişimlerinden dolayı ambalaj içindeki suyun sürekli rehidrasyon ve dehidrasyona maruz kalması ile gıda yüzeyinde nem yoğuşması görülmekte ve bu da mikrobiyal çoğalma olasılığını arttırmaktadır [6, 7]. Ürünün depolama ve dağıtımı sırasında maya, küf ve bakteri üremesi gıda kalitesini ve gıda güvenliğini olumsuz yönde etkilemektedir. Benzoik asit, sodyum benzoat, sorbik asit, potasyum sorbat ve/veya propiyonik asit gibi antimikrobiyallerin kullanımı, ilave bir gıda koruma aracı olarak görülmektedir. Yenilebilir kaplamalar, gıda yüzeylerinde katk1 maddelerinin tutulmasındaki etkinliklerinden dolayı antimikrobiyal taşıyıcılar olarak incelenmiştir. Son yıllarda, bazı araştırmacı gruplar model sistemlerdeki sorbik asit ve potasyum sorbatın difüzivitesini değerlendirmişlerdir [8, 9, 10]. Vodjani ve Torres [9], yüzey mikrobiyal stabilitenin soğutulmuş et ürünlerinin raf ömrünün ana belirleyicisi olduğunu belirtmişlerdir. Bunu önlemek 
amacıyla antimikrobiyal ajanların gıdada difüzyonunu kontrol etmek için yenilebilir film ve kaplamalar kullanmışlardır. Çalışmada laurik, palmitik, stearik ve arakidik asit ilaveli metil ve hidroksipropil metilselüloz filmlerinin, yağ asidi içermeyen selüloz eter filmlerine göre potasyum sorbat geçirgenliği oranı önemli ölçüde düşmesiyle ürünlerin raf ömrünü uzatmada yapıda daha uzun süre etkili olduğu sonucuna varmışlardır. Torres ve Karel [10], bir zein kaplaması tarafından kontrol edilen yüksek bir yüzey sorbik asit konsatrasyonunun etkinliğini Staphylococcus aureus'a karş1 doğrulamışlardır. Kaplanmamış numuneler sadece 3 gün stabil kalırken, bu şekilde işlem gören orta nemli gıdaların 16-28 gün arasında bir depolama süresi boyunca mikrobiyal olarak stabil kaldığını gözlemlemişlerdir

Daha önceki zamanlarda yapılmış olan araştırmalarda, gıdaları bir çözelti içine daldırarak antimikrobiyal etki oluşturmak üzerine odaklanılmıştır. $\mathrm{Bu}$ yöntemi kullanan Eckert ve Kolbezen [11], uygulamanın başlangıçta toplam canlı mikroorganizma sayısının azaltılmasında etkili olduğunu, ancak depolama sırasında gıdaya işlemiş olan koruyucu maddenin yüzeyde yapı bozulmalarına sebep olduğunu belirtmişlerdir. Çalışmada balmumu formülasyonuna benzimidazol fungusitleri işlenerek narenciye meyveleri daldırma ile kaplanmıştır ve özellikle narenciyelerin hasattan sonra uzun mesafeli nakliyesinde başlıca sorun olan Penicillium spp. üzerine odaklanılmıştır. Sonuçlarda 1 $\mathrm{mg}$ fungusit/kg meyve dozunun ürünün korunmasında etkili olduğu fakat benzimidazol fungusitlerin etkinliğinin uygulama yönteminden etkilenerek alkali balmumu formülasyonlarında ve organik çözücülerde benomilin parçalanması ile yüzeyde kalıntıların oluştuğu gözlemlenmiştir [8].

Yenilebilir film ve kaplamalar için bir matris malzemesi olarak kitosan birçok araştırmacı tarafından incelenmiştir. Kitosan filmleri Listeria monocytogenes [12] ve Aspergillus niger [13] gelişimini önleyebilmektedir. Pektin ile birlikte kullanılan kitosan, yenilebilir filmlerin mekanik özelliklerini geliştirmektedir [14]. Kitosan, Alternaria spp., Penicillium spp., Aspergillus spp. ve Cladosporium spp.'ye karşı koruma için pizza hamuruna ilave edilen bir bileşen olarak araştırılmıştır [15]. Taze çileklerde ise kitosanın hidroksipropil metilselüloz ile birleştirilmesiyle, Cladosporium spp. ve Rhizopus spp. çoğalması kontrol edilmiştir [16]. Uçucu yağlara sahip zenginleştirilmiş kitosan filmlerden verimli sonuçlar elde edilmiştir. $\mathrm{Bu}$ katkılar, derisiz somon filetolarını Listeria monocytogenes'e [17] karş1 korurken, nem kaybının ve lipit oksidasyonunun da önlenebildiği 
gösterilmiştir [18]. Işınlama ile orta nemli et ürünlerinde kitosan kaplama, antioksidan ve antimikrobiyal etki göstermiştir [19]. Pişirilmiş kıyma ve hindi üzerine uygulandığında ise soğuma sırasında Clostridium perfringens sporlarına karşı koruyucu bir etkisi olmuştur [20].

\section{Antioksidanlar}

Antioksidanlar, gıda bileşenlerinin, özellikle lipitlerin stabilitesini arttırmakta ve oksidatif ransisite, bozulma ve renk bozulmasını önleyerek besin değerini ve rengi korumaktadır. Asit veya fenolik bileşikler antioksidanlar olarak işlev görmektedir. Sitrik ve askorbik asit gibi asit bileşikleri, metal şelatlayıcı ajanlardır. Bütillenmiş hidroksianisol (BHA), bütillenmiş hidroksitolüen (BHT), üçüncül bütillenmiş hidroksikinon (TBHQ), propil gallat ve tokoferoller gibi fenolik bileşikler lipit oksidasyonunu inhibe etmektedir. Bu antioksidanlar, yenilebilir kaplamalara dahil edilebilmekte ve gida yüzeyinde tutundurulabilmektedir. Yenilebilir kaplamalar, enzimatik oksidasyon gibi enzimatik işlemleri de azaltabilmektedir [21].

Yenilebilir Film ve Kaplamalara Katkı Maddelerinin Eklenme Teknikleri

Filmlerin ve kaplamaların formülasyonu, genel olarak, yapışkan bir yapısal matris oluşturabilen en az bir bileşen içermelidir. İki veya daha fazla matris maddeden yapilan yenilebilir filmler, her bir bileşenin spesifik fonksiyonel özelliklerinden yararlanmak ve dezavantajlarını en aza indirmek için kullanılabilmektedir. İncelenen kompozit filmlerin çoğu genellikle bir lipit ve hidrokolloid gibi hidrofobik bileşiklerin birlikte kullanılmasıyla elde edilen matrislerden oluşmaktadır.. Film oluşturucu maddeler, matris molekülleri arasındaki etkileşimler, bir kimyasal maddenin eklenmesinden sonra veya fiziksel bir işlemle sürekli bir yapı oluşturabilir. Film ve kaplama yapımı aşağıdaki işlemlerden birini içermektedir [22]:

- Katı yağların, vaksların veya reçinelerin eritilmesi ve katılaştırılması.

- Sulu çözelti içinde dağılmış bir hidrokolloidin çözücünün uzaklaştırılmasıyla çökeltildiği veya jelleştirildiği basit koaservasyon; polimerin çözünür olmadığı, elektrolit olmayan bir çözünen maddenin eklenmesi; tuzla çökelme etkisine neden olan bir elektrolit maddesinin eklenmesi; veya $\mathrm{pH}$ modifikasyonu.

- Karşılık gelen yüklere sahip iki hidrokolloid çözeltinin birleştirildiği kompleks koaservasyona neden olan 
etkileşimler ve polimer karışımının çökmesi.

- Denatürasyon, jelleşme ve çökelme içeren makromolekül çözeltisinin 1sitılması veya hidrokolloid çözeltisinin hızlı soğutulması yoluyla termal jelleşme veya pıhtılaşma.

\section{Çok Katlı Kaplamalar}

Lipitler ve biyopolimerler, "emülsifiye edilmiş" veya çift katmanlı film ve kaplamalar oluşturmak için kullanılmaktadır. Emülsiyon bazlı yenilebilir ambalajlama için, su buharı bariyeri etkinliği, birleştirilen lipitlerin yani yağ asitlerinin zincir uzunluğunun yapısına ve filmi oluşturan emülsiyonun yapısına bağlıdır. İki tabakalı filmler, nem transferine karşı emülsifiye edilmiş filmlerden 10-1000 kat daha iyi bariyer verimliliğine sahiptir. Lipit bazlı yenilebilir filmlerin fonksiyonel özellikleri k1smen, lipit molekülünün doğası (polarite) ve yapısının (katı yağ içeriği, kristal tipi) bir kombinasyonu ile açıklanmaktadır. Literatürdeki araştırmalarda en hidrofobik lipitlerin en iyi bariyer verimliliğine sahip olduğu bilgisine yer verilmiştir. MartinPolo ve Voilley [23], katı yağ içeriğinin parafin mumları ve saf alkanlar için \%20'den yüksek olduğunda lipit tabakalarının geçirgenliğinin önemli ölçüde azaldığını bildirmiştir. Bununla birlikte, lipit kristal tipinin (ortofobik) ne kadar kararlı olduğu, nem geçirgenliğinin azalması ile ilişkilendirilmiştir [1]. Lipit ve hidrokolloid bileşenlerin avantajlarını birleştirmek için çok katmanlı kaplamalar formüle edilebilir. Neme karşı bir engel oluşturmak istendiğinde, lipit bileşeni bu işlevi yerine getirirken, hidrokolloid bileşeni gerekli yapı ve dayanıklılı̆̆ sağlamaktadır [24]. Gıda katk1 maddelerinin eklenmesiyle ilgili olarak, çok katmanlı filmler, kaplamanın farklı kutuplardaki bileşikleri taşımasına izin vererek hem lipofilik hem de hidrofilik faz avantajını sunmaktadır [5].

\section{Mikro-Nano Emülsiyonlar}

Diğer yenilebilir film türlerine göre daha az çalışılmış olan emülsifiye edilmiş filmlerin, homojen olmayan lipit maddesi dağılımı nedeniyle iki tabakalı filmlerden 100 kat daha az etkili oldukları fakat iki katmanlı filmlerin oluşturulması için gerekli olan basamaklar yerine sadece bir kurutma aşamasına ihtiyaç olması avantajına sahiptirler. Ayrıca oda sıcaklığında yiyeceklere de uygulanabilirler. Hem hidrofilik hem de lipofilik bileşenlerin varlığı, kutupları ne olursa olsun, emülsiyon bazlı filmlerin veya kaplamaların herhangi bir desteğe yapışmasını sağlamaktadır. Bir lipit tabakası zayıf mekanik dirence sahipken, 
bir lipit-hidrokolloid emülsiyon bazlı film iyi mekanik direnç göstermektedir [5].

Emülsifiye filmler yoluyla bileşen taşınımını açıklamak için iki model önerilmiştir. Birincisi, gazların ve buharların kütle transferinin, emülsiyonun kurutulması sirasında hidrofobik malzemenin mikro parçacıkları ve hidrokolloid matrisi arasında oluşan mikro boşluklar yoluyla meydana geldiğini öne süren 'mikro boşluk' modelidir. Alternatif bir model olan 'mikro yol modeli', polimer matrisinin kendisinde kütle transferinin gerçekleştiğini göstermektedir. Emülsiyon özellikleri, emülsifiye edilmiş fillmlerin mekanik ve bariyer özelliklerini önemli ölçüde etkilemektedir. Lipit globüllerinin çapı ne kadar küçük ve homojen olursa, bariyer özellikleri o kadar iyi olmaktadır. $\mathrm{Su}$ buharı geçirgenliği ise bileşenlerin hidrofobikliği arttıkça düşmektedir, buna dayanarak mumların, yenilebilir filmlerin ve kaplamaların su geçirgenliğini azaltmada en etkili bileşenler olduğu bulunmuştur. Yağ asidi zincirinin uzunluğu geçirgenliği etkilemektedir. Palmitik ve stearik asitler, kaprik veya behenik asitlerle karşılaştırıldığında en iyi etkinliği göstermiştir. Film kurutma sırasında emülsiyonun oluşturulması, emülsifiye edilmiş filmlerin izotropik olmayan doğasından kaynaklanmaktadır. Filmin bir tarafı, artan protein içeriği nedeniyle parlak iken, diğer tarafı artan lipit içeriği nedeniyle opaktır. Su buharı iletim testi sırasında yüksek bağıl nem ortamına bakan lipit bakımından zenginleştirilmiş tarafa yönelik filmlerin daha düşük geçirgenlik gösterdiği de gözlenmiştir. Lipit içeriğindeki bir artış, emülsifiye edilmiş buğday glüteni bazlı filmler için mekanik verim kaybına neden olmuştur. \%35-40'tan yüksek lipit konsantrasyonları için, emülsifiye edilmiş filmler daha kırılgan ve geçirgen hale gelmiştir [25].

Emülsifiye edilmiş kaplama türü iyi bir nem bariyeri sağlamakta, ancak ürün için olumsuz özellikler de sağlayabilmektedir. Lipitler, suda bir makroemülsiyon (partikül büyüklüğü aralığı: $2 \times 10^{3}-10^{5} \AA$ ), bir mikroemülsiyon (partikül büyüklüğü 1000-2000 Å) veya bir nanoemülsiyon (partikül büyüklüğü<1000 A) olarak yayilmaktadir. Mikroemülsiyonların formülasyonu hem dağılmış hem de sürekli fazlarla uyumlu olan uygun emülgatörlerin seçilmesini gerektirmektedir. Dağınık ve sürekli fazlarda kısmen çözünür bir yüzey aktif madde kullanılmaktadır ve yardımcı bir yüzey aktif madde tipik olarak bir alkoldür [26]. Yenilebilir kaplamalarda mikroemülsiyonlar istenmektedir, çünkü küçük damlacık boyutu lipit fazının 
homojen bir film halinde birleşmesini sağlamaktadır. Yüksek basınçlı valf homojenizatörlerinin veya mikro akışkanlaştırıcıların kullanımı ile 100-500 nm damlacık çaplarına sahip emülsiyonlar üretilebilir. $\mathrm{Bu}$ emülsiyonlar genellikle 'nanoemülsiyonlar' olarak adlandırılır. İşlevsel gıda bileşenleri damlacıkların içine, arayüzler arasındaki bölgeye veya sürekli faza dahil edilebilir [27]. Arayüzlerdeki geçirgenlik oranını tespit etmek kolay bir işlemdir ve bu oran düzenlenebildiği takdirde fonksiyonel bileşenler kimyasal bozulma işlemlerini yavaşlatabilir. Kitosan türevlerinin misel oluşturucu özellikleri, Zhang vd. [28] tarafından kontrollü salınım ve hidrofobik biyoaktif gıda bileşenlerinin hedeflenmiş dağıtımındaki potansiyellerini daha iyi anlamak için çalışılmıştır. Çalışmada, altı yeni N-alkil-N-dimetil ve $\mathrm{N}$-alkil-trimetil kitosan türevi kimyasal olarak sentezlenmiş ve karakterize edilmiştir. $\mathrm{Bu}$ kitosan türevlerinin ayrıca dinamik 1şık saçılımı (DLS) ve transmisyon elektron mikroskobu (TEM) teknikleri kullanılarak da misel oluşturucu özellikleri değerlendirilmiştir. altı kitosan türevinin tümünün, 36-218 nm arasında değişen ortalama bir partikül çapına sahip suda polimerik miseller oluşturabildiği gözlemlenmiştir. Misel boyutunun ise alkil grubunun uzunluğu ve kitosan türevlerinin
N-trimetilasyon derecesi ile değiştiği vurgulanmıştır [25].

\section{Mikrokapsüller ve Lipozomlar}

Mikroenkapsülasyon, yiyeceklere, farmasötiklere, kozmetik ürünlerine ve böcek ilaçlarına uygulanan, polimerik bir kaplamadaki parçacıkların, damlacıkların veya gazların tutulması işlemidir [29]. Mikroenkapsülasyon uygulanan bileşenler asitleştiriciler, lezzet vericiler, renk maddeleri, kabartma ajanları, tuzlar, enzimler, yapay tatlandırıcılar, mineraller ve vitaminleri içermektedir. Mikrokapsül üretiminde zamk, nişasta ve nişasta türevleri, selülozik türevler, lipitler, proteinler ve inorganik maddeler kullanılmaktadır [30].

Çoklu emülsiyonların kullanımı, yeni kapsülleme ve iletim özelliklerine sahip dağıtım sistemleri oluşturabilir. Örneğin, fonksiyonel gıda bileşenleri, bir su/yağ/su emülsiyonunun içteki su fazına alınabilirken, bu emülsifiye edilmiş bileşenlerle ters şekilde reaksiyona girebilen diğer bileşenler ise dıştaki su fazında çözünebilir. Bu yöntem, sindirim sistemi içindeki belirli bir bölgedeki bileşenleri korumak ve serbest bırakmak için kullanılabilmektedir [27].

Lipozomlar veya lipit kesecikleri, doğada bol miktarda bulunan polar 
yağlardan, özellikle soya ve yumurtadan gelen fosfolipitlerden oluşmaktadır. $\mathrm{Bu}$ yapılar hem suda hem de yağda çözünür bileşikleri kapsüllemek için kullanılabilirler. Lipozomlar, iki katmanlı bir kabuk konfigürasyonuna sahip küresel, polimoleküler yığınlardır [31]. Lipozomlar üzerine yapılan çeşitli çalışmalarda, süt ürünlerinde bakteriyostatik uygulamalar için laktoferrin ve nisin Z'nin kapsüllenmesi ve süt ürünleri ve et ürünlerinin kalitesini arttırmak için antioksidan fosvitin ve C vitamininin lipozomlarla kapsüllenmesi incelenmiştir [32].

\section{Gidalarda Mevcut Uygulamalar}

Araştırmalar bitkilerden ve baharatlardan elde edilen özütlerin ve doğal bileşenlerin film ve kaplamalara dahil edilmesinin antioksidan, antimikrobiyal ve anti-esmerleşme gibi aktif özelliklerini geliştirdiğini göstermiştir [33, 34, 35]. Yenilebilir kaplamalar üzerindeki aktif katkı maddeleri, raf ömrünü arttırarak gıda ürünlerine değer katmaktadır [36, 37, 38].

\section{Meyve ve Sebzeler}

Yapılan çalışmalarda narenciye meyveleri üzerinde antimikrobiyal ve fungisitlerin emülsiyon ve su süspansiyonlarındaki uygulamaları incelenmiştir. Bazı araştırmacılar Valencia portakalları üzerine imazalil (küf ve mantarlara karşı kullanılan bir ilaç) [39]; greyfurt üzerine sorbik asit, tiyabendazol ve benomil; şeftali ve nektarin üzerine 2,6dikloro-4 nitroanilin (DCNA) [40]; papaya üzerine tiyabendazol [41]; çilek üzerine iprodin ve kitosan [42]; domates üzerine Captan fungusid ve tiram uygulanmasında iyi sonuçların ortaya çıktığını bildirmişlerdir. 1metilsiklopropen, minimal işlenmiş marulda etilene bağlı etkileri azaltmak için daha iyi özellikler gösterse de aljinat bazlı kaplama, gevrekliği koruyarak her ikisini de kombine faydalar için kullanma imkanı sağlamıştır [44]. Tatlı mısır üzerine uygulanan zein kaplamanın Listeria monocytogenes popülasyonundaki azalma üzerine tek başına kullanımında etkili olduğu gösterilmiş ve ayrıca kaplamaya bir antimikrobiyal bileşen olarak sorbik asit ilave edildiğinde herhangi bir ek fayda sağlamadığı bildirilmiştir [45]. Yenilebilir kaplamaların guavanın raf ömrünü artırmak için iyi bir seçenek olabileceği düşünülmüş ve su buharı ve aroma (2-pentanon) geçirgenliği karşılaştırılırken, yapılan testler ile guavayı korumak için yenilebilir ambalaj verimliliğinin su buharından daha fazla hidrofobik elementlerin tutulmasına bağlı olduğu gösterilmiştir [46]. 


\section{Unlu Mamuller}

Tatlı tat, genellikle kahvaltılık gevrekler için tüketiciler tarafından en çok istenen tat olmasından dolayı tahıllar için kullanılan kaplama malzemelerinin çoğu şeker bazlı bir yapıya sahiptir. Kaplama formülasyonlarındaki katkı maddeleri, aroma ve kaplamanın kahvaltı gevreği ürünü üzerine yapışmasını daha etkili hale getirmektedir. Asetik asit ve sodyum asetat tadı iyileştirmek için kullanılırken kaplama kıvamını değiştirmek için koyulaştırıcı maddeler, emülgatörler (örneğin lesitin), nemlendiriciler ve plastikleştiriciler (sorbitol) kullanılmaktadır. Asetik asit, kalsiyum propiyonat veya potasyum sorbat içeren kitosanın, önceden pişirilmiş pizzalarda yenilebilir bir kaplama olarak kullanımının mikrobiyal üremeyi geciktirerek hamuru koruduğu fakat Maillard reaksiyonlarının antimikrobiyal kapasitenin düşmesine neden olduğu bildirilmiştir [15].

Unlu mamuller üzerine farklı polisakkarit bazlı yenilebilir kaplamaların sodyum benzoat ile uygulanması, ürünlerin raf ömürlerinde en az \%100'lük bir artışa sebep olurken, ilk 100 saat boyunca ise su kaybını \%50 oranında azalttığı belirtilmiştir. Su kaybının kinetiği; (1) 48 saat boyunca yüzeydeki su kaybı, (2) suyun içeriden göçüne karşılık gelen bir dengeleme ve (3) üründe nem kaybının devam etmesi şeklinde üç fazlı bir mekanizma ile ifade edilmiştir. Bir biyopolimerin ve bir kaplama olarak uygulanan bir katk1 maddesinin kombinasyonu hem ürün hem de kaplama içinde dağıtıldığı zaman katkı maddeleri olduğunda daha iyi sonuçlar vermiştir. Karşılaştırmalı duyusal değerlendirme sonuçlarına dayanarak, kaplamanın tüketici tercihini etkilemediği gözlemlenmiştir [47].

\section{Heterojen Gidalar}

Bazı gıda ürünleri bileșenleri, renk ve/veya beslenme kalitesinde değişiklikler meydana getirebilecek diğer bileşenlerle reaksiyonlara girebilir. Genellikle, kompozit bir gıdanın bileşenlerini ayırmanın tek pratik yöntemi, bileşenler arasında yenilebilir bir film tabakasını bariyer olarak kullanmaktır [48]. Yenilebilir kaplamaların performans1, dondurulmuş pizza, dondurma, tahı1, kuru üzüm, kurutulmuş meyveli kek ve peynir gibi çeşitli heterojen ürünler üzerinde geniş bir şekilde incelenmiştir [49-52].

\section{Çeşitli Gıda Uygulamaları}

Clostridium perfringens'in pişmiş kıyma ve hindi üzerindeki inhibisyonu, etin \%3 konsantrasyonda kitosan ile kaplanmas1 ile sağlanmıştır [20]. Triklosan içeren bir stiren-akrilat kopolimerden yapılan bir kaplama etkili bir antimikrobiyal tabaka 
olarak değerlendirilmiştir [53]. Nisin içeren zein film kaplamanın, yemeye hazır et ürünlerinin yüzeyinde Listeria monocytogenes'in kontrolünde etkili olduğu bildirilmiştir [54]. Bazı araştırmacılar, yenilebilir kaplamaların özellikleri, film bileşenleri ve antimikrobiyal ajanların iletilmesi hakkında çalışmalar yapmıştır [55].

Kitosan filmlerinin, Emmental peyniri üzerine aşılanan Listeria monocytogenes üzerinde engelleyici bir etki gösterdiği sonucuna varılmıştır [56]. \%1 paminobenzoik asit (PABA) içeren yenilebilir kaplamaların, Listeria monocyogenes'e karşı diğer ticari kaplamalardan daha fazla inhibe edici olduğu ve sosisli sandviçlerde Listeria büyümesinin 42 günlük soğutmalı depolama sirasında baskıladığı bildirilmiştir [57]. Başka bir çalışmada ise taze Atlantik morina filetolarının kitosan bazlı kaplamalarla kaplanması, nispi nem kayıplarında önemli bir azalma göstermiş ve lipit oksidasyonu ve toplam uçucu bazik azot miktarı da azaltılmıştır [5].

F1stıkları kaplamak için gliserol (plastikleştirici), lesitin (yüzey aktif madde), metil paraben (antimikrobiyal) veya $\mathrm{E}$ vitamini (antioksidan) içeren peynir altı suyu proteini bazlı kaplamaların formülasyonları kullanılmıştır. Heksanal analizi ile bu formülasyonlar ile kaplanmış numunelerin, kaplanmamış referanstan önemli ölçüde daha yavaş oksitlendiği gösterilmiştir [58].

\section{Gelecekteki Uygulama Potansiyeli}

Gıda katkı maddelerinin kullanımı ile ilgili gelecekteki teknolojiler üzerinde, sağlık ve üretim maliyetleri konusundaki etkileri azaltma ve ayrıca gidaların nihai görünümünde minimum etkinin oluşması amacıyla çalışmalar yapılımıştır. Zaten farklı amaçlar için yaygın olarak kullanılan nanoteknoloji, yenilebilir film ve kaplamara, katkı maddelerinin içine alınması, kontrollü salınımlara izin verilmesi, kararlılı̆̆ı artması ve nihai üründeki etkinin azaltılması için de uygulanmaktadır. Yakın bir gelecekte, gidada veya pakette bulunan bu nano yapıların çürümeyi veya kontaminasyonu tespit etmesi ve sadece belirli antioksidanların veya antimikrobiyallerin salınımına başlaması beklenmektedir [5963].

Yenilebilir film ve kaplamalar ile yaygın olarak taşınımı sağlanan koruyucu maddeler ve antimikrobiyaller, asetik ve laktik asitler, parabenler, sorbatlar, propiyonatlar, benzoatlar gibi asitleştirici maddeler, lisozim ve esansiyel yağlar, bakteriyosinler ve sodyum nitrat ve sodyum 
klorür gibi sertleştirici maddelerdir. Esansiyel yağlar, çeşitli bitki ve hayvanlardan ekstrakte edilmiş bileşikler, bakteriyosinler, enzimler, organik asitler, nano boyutlu metal oksitler ve bakteriyofajlar antimikrobiyal özellikte yenilebilir film ve kaplama üretiminde kullanım için birçok araştırmaca yaygın olarak incelenmiştir [64-66].

Gelecekteki eğilimlerde, tüketici taleplerine dayalı sistemlerin oluşturulması gerekmektedir. $\mathrm{Bu}$ gelişmelerin temel amacı, çok katmanlı sistemler ve nanokapsülasyon gibi nanoteknoloji kullanarak aktif bileşiklerin yani koruyucu gıda katkı maddelerinin salınımını kontrol edebilmektedir. Nanoteknoloji, belirli koşullar altında bu aktif bileşiklerin salınımını kontrol etmekte, dolayısıyla onları 1sı, nem, güneş 1şı̆̆ı ve diğer olumsuz etkenlerden koruyarak stabilite ve verimliliklerini arttırmaktadır. Nanoteknoloji, gıda katkıları için nano boyutta taşınım sistemlerinin ve nano ölçekli katkı maddelerinin besin değerini arttırmak için de yenilebilir film ve kaplama teknolojisine uyarlanabilmektedir. Enkapsülasyon için en çok tercih edilen kaplama materyali aljinat bazlı olanlardır, ancak diğer biyopolimer de sıklıkla kullanılmaktadır. Kapsülleme için en uygun maddeler ise prebiyotik, probiyotik ve enzimlerdir [67].

Gelecekteki araştırmalar, farklı gıda maddeleri için ideal bileşiği veya bileşikleri bulmak yerine, gıda maddesi için spesifik bileşikler içeren uygun film ve kaplamalara odaklanılmalıdır.

\section{Probiyotik Ajanlar}

Probiyotikler, insan sağlığı üzerinde faydalı etkilere sahip canlı mikrobiyal besin bileşenleri olarak tanımlanmaktadır. Probiyotik kavramı, Bulgar köylülerinin sağlıklı yaşamlarının fermente süt ürünleri tüketiminden kaynaklandığı hipotezinden evrilmiştir [68]. Tarih boyunca en çok incelenen probiyotik bakteriler, Lactobacillus ve Bifidobacterium cinslerinin üyelerini içermektedir. Saccharomyces boulardii, Escherichia coli ve Enterococcus suşları, gıda dışı formlarda probiyotik olarak kullanılmaktadır. Probiyotik bakterilerin laktoz sindirimine yardımcı olma, enterik patojenlere karşı direnç sağlama, immün sistem modülatörü olarak görev alma ve anti-ürogenital enfeksiyonların ve hepatik ensefalopatinin önlenmesi gibi bazı potansiyel veya yerleşik etkileri bildirilmiştir [69]. Probiyotiklere dünya çapında artan ilgi, bu ürünler için günden güne genişleyen bir pazarın oluşumunu sağlamıştır. Probiyotikler insan sağlığına yararlı 
bileşenlerdir ve bu bileşenlerin olumlu etkileri sağlıklı diyet stratejileri ile daha da arttırilabilir [68].

Yenilebilir film ve kaplamalar gida ürünleri içinde veya yüzeylerinde çeşitli canlı probiyotikler için ideal dağıtım sistemleri olarak görülmektedir. Probiyotiklerin yenilebilir film ve kaplamalar ile taşınması, yenilebilir bir film üzerindeki canlı mikroorganizma sayılarını kontrol etme olanağı sunarken, aynı zamanda gıdaların üretimi, depolaması, tüketimi ve sindirimi sırasında sıcaklık, $\mathrm{pH}$, kimyasal ve enzimatik süreçlerdeki değişikliklere karşı koruma da sağlamaktadır [70]. Bu faktörlerin yanısıra, probiyotiklerin yaşayabilirliği gastrointestinal kanaldan geçmeleriyle belirlenmektedir ve burada ise asıl engeller düşük $\mathrm{pH}$ ve safradır. $\mathrm{Bu}$ sınırlamalara çözüm bulmak ve canlılık oranını arttırmak için probiyotiklerin yenilebilir film ve kaplamalara katılması veya bunların polimerik matrislere mikrokapsüllenmesi gibi farklı teknolojik stratejiler geliştirilmektedir [71].

\section{Nutrasötikler}

Tüketicilerde besleyici g1dalara yönelik bilincin ve buna bağlı Pazar talebinin artmasıyla birlikte besinsel olarak takviye edilmiş gıdaların üretimi öne çıkmaktadır. Taze meyve ve sebze gibi minimum işlenmiş gıdalara besin takviyesi yapmak için geliştirilen alternatif yöntemlerden biri de belirli konsantrasyonlarda nutrasötik madde içeren yenilebilir film ve kaplamaların kullanılmasıdır. Gıda ürünleri, besin takviyeli kaplama veya filmler ile kaplanabilmekte ve sarılabilmektedir. Mei ve Zhao [72] tarafindan yapilan bir çalışmada, süt proteini bazlı (kalsiyum kazeinat ve peynir altı suyu proteini izolatı) yenilebilir filmlere yüksek kalsiyum ve $\mathrm{E}$ vitamini konsantrasyonları eklendiğinde, su buharı geçirgenliğinin ve gerilme özelliğinin olumsuz etkilendiği gösterilmiştir. E vitamininin dahil edilmesi ile filmlerde kopma sırasındaki uzama yüzdesinin artarken vitaminin hidrofobik doğası, plastikleştirici etkisi veya filmin heterojen yapisı nedeniyle de gerilme mukavemetini azalttığı belirtilmiştir.

Bazı nano ölçekli taşınım sistemleri, nutrasötik ve fonksiyonel g1da formülasyonu ile üretim süreçlerinde kullanılmıştır. Nanoteknolojiye dayanan yeni konseptler, ürün işlevselliğini ve taşıma verimliliğini arttırmak için araştırılmaktadır [31]. Emülsiyon, dispersiyon ve yapılandirılmış akışkan/sıvılar geniş ara yüzey alanına sahip sistemlerdir. $\mathrm{Bu}$ sistemlerin bileşen taşımaya yönelik işlevselliklerinin daha iyi 
anlaşılması için nano boyuta indirgenerek karakterizasyonu yapılmalıdır. Bu anlayış, çözünürlüğü arttıran, kontrollü salınımı kolaylaştıran, biyoyararlanımı geliştiren ve işleme, depolama ve dağıtım sırasında mikro besinlerin ve biyoaktif bileşiklerin stabilitesini koruyan gıda ürünleri için potansiyel olarak yeni bir aktif ambalajlama türünün geliştirilmesine olanak sağlayabilir.

\section{Uçucu Bileşikler}

Yenilebilir bir film boyunca buhar transferine karşı bariyer verimliliği esas olarak sorpsiyon ve difüzyona bağlıdır. Polimer-uçucu bileşik ilişkisini açıklamak için kullanılan sorpsiyon mekanizması, nüfuz edici moleküllerin adsorpsiyon, absorpsiyon ve/veya desorpsiyonundan oluşur. Diğer taraftan difüzyon, materyalin polimerik ağı içindeki uçucu bileşiklerin hareketliliği ile ilgilidir. Transfer işlemini açıklamak için uçucu bileşik ve film polimer özellikleri dikkate alınmalıdır. Bununla birlikte, polimerizasyon tipi, polimer üç boyutlu yapısı, zayıf enerji bağları ile tutulan malzeme kohezyonu ve polimer camsı geçiş sıcaklığı gibi diğer yapisal faktörler sorpsiyon ve difüzyonu etkileyebilir [73]. Ek olarak uçucu bileşiklerin fizikokimyasal özellikleri filmin geçirgenliğini, aroma bileşiklerinin şekli ve boyutu ise difüzyon gücünü etkileyebilir. Çözünürlük kavramı da bileşiğin doğası, polaritesi ve yoğunlaşma yeteneğinden etkilenebilir.

Çözünmüş madde polaritesi sorpsiyon işleminde önemli bir faktördür. Bazı araştırmacılar, polaritelerin benzer olması halinde aroma bileşiklerinin polimerik film üzerinde daha kolay adsorbe olduğunu göstermiştir. Bununla birlikte, çok az sayıda araştırmacı ise bu faktörün hidrofilik yenilebilir ambalaj yoluyla aktarım üzerindeki etkisini incelemiştir. Ayrıca, yenilebilir filmlerin aroma bariyer özellikleri, su ve oksijen transferi kadar ayrıntılı olarak çalışılmamıştır 74].

Geçirgenlik ve sorpsiyon ile geçirgenlik ve doymuş buhar basıncı arasında bir ilişki vardır. Kütle transferi, esas olarak uçucu bileşik ve polimer arasındaki ilişkiye bağlı gibi görünmektedir. Bu ilişki, polimerin yapısını değiştiren fizikokimyasal etkileşimlerin varlığını (plastikleşme) göstermektedir.

Uygulamalı nanoteknoloji, gida kalitesini ve işlevselliğini geliştirmek için yeni bileşen taşıyıcı sistemlerin geliştirilmesine ve bu sistemlere uyarlanabilecek olan kontrollü salınım ise ürünlerde tat ve renk modifikasyonuna yol açabilir [31]. 


\section{Modifiye ve Kontrollü Atmosfer Kullanımı}

Genel olarak, kontrollü veya modifiye atmosferlerin kullanımı, minimum işlenmiş ürünler için faydalıdır. Tipik olarak, bu ürünlerin raf ömrünü uzatmak için \%5-10 $\mathrm{CO}_{2}$ ve \%2-5 $\mathrm{O}_{2}$ aras1 bir konsantrasyon uygulanmaktadır. Katk1 maddelerinin taşınmasında kullanılan yenilebilir film ve kaplamaların kontrollü ve modifiye atmosfer uygulamaları ile birlikte kullanımı olumlu sonuçlar vermektedir. Amanatidou vd. [75], dilimlenmiş havuçlar üzerinde aljinat bazlı yenilebilir kaplama ile modifiye atmosfer uygulamasını bir arada kullanarak havuçların çeşitli fizikokimyasal ve mikrobiyolojik özelliklerinin depolama süresi boyunca korunduğunu bildirmişlerdir..

\section{Sonuç}

Yenilebilir film ve kaplamalar çok eski zamanlardan günümüze kadar gıdaların raf ömrünü arttırmak için kullanılmaktadır. $\mathrm{Bu}$ sistemlerin etkinliğinin arttırılmasında, biyopolimerler ile katkı maddeleri gibi küçük moleküllerin taşınması oldukça verimli bir yaklaşımdır. Film ve kaplamaların yapısına antimikrobiyaller ve antioksidanlar gibi bileşenlerin ilave edilmesi, birçok gida ürününde bozulmanın esas nedeni olan mikrobiyal çoğalmayı önleyebilmekte veya yavaşlatabilmektedir.
Benzoik asit, sodyum benzoat, sorbik asit, potasyum sorbat, propiyonik asit gibi antimikrobiyaller ve BHA, BHT, TBHQ, propil gallat, tokoferoller gibi antioksidanlar yenilebilir kaplamalara dahil edilerek gıda yüzeyinde daha etkili bir şekilde tutundurulabilirler. İlave koruma aracı olarak değerlendirilen bu bileşikler yenilebilir film ve kaplamalara çok katlı kaplamalar, mikro-nano emülsiyonlar, mikroenkapsüller ve lipozomlar şeklinde dahil edilebilmektedir. $\mathrm{Bu}$ tekniklerin seçimi, birden fazla bileşen kullanımında her bir bileşenin spesifik fonksiyonel özelliklerinden yararlanma amacı ile ilişkilidir. Çok çeşitli ürün yelpazesinde kullanılan bu sistemlerin günümüzdeki uygulamaları çok etkili sonuçlar sunmaktadır. Yenilebilir film ve kaplama teknolojisi gıda korumada oldukça etkili olmasının yanı sıra çeşitli katkıların yapıda taşınmasına imkan sunmasından dolayı araştırmaya ve geliştirmeye de açık bir teknolojidir.

Probiyotiklerin, nutrasötiklerin, uçucu bileşiklerin ilavesi ve diğer g1da koruma sistemleri (modifiye ve kontrollü atmosfer gibi) ile birlikte kullanılması gibi yenilikçi yaklaşımlar, bu sistemlerin sahip oldukları avantajları arttırabilir ve böylece gelecekte g1da muhafazasında en etkili ve verimli yöntem olmasını sağlayabilir. 


\section{Kaynaklar}

[1] Debeaufort F, Quezada-Gallo JA, Delporte B, Voilley A, 2000. Lipid hydrophobicity and physical state effects on the properties of bilayer edible films, J Membrane Sci, 180: 47-55.

[2] Huber KC, Embuscado ME, QuezadaGallo JA, 2009. Delivery of food additives and antimicrobials using edible films and coatings. Edible films and coatings for food applications, 315-333.

[3] International Food Information Council (IFIC) and U.S. Food and Drug Administration (FDA), 2010. Overview of Food Ingredients, Additives \& Colors.

[4] FDA, 1999. Guidance for Industry: Antimicrobial Food Additives.

[5] Quezada-Gallo JA, 2009. Delivery of food additives and antimicrobials using edible films and coatings. In: Embuscado ME, Huber KC (eds) Edible Films and Coatings for Food Applications, Springer, New York, NY, p. 315-333.

[6] Torres JA, Bouzas JO, Karel M, 1985a. Microbial stabilization of intermediate moisture food surfaces, II. Control of surface pH, J Food Process Preserv, 9: 93 106.

[7] Torres JA, Motoki M, Karel M, 1985b. Microbial stabilization of intermediate moisture food surfaces, I. Control of surface preservative concentration. J Food Process Preserv, 9: 75-92.

[8] Guilbert S, 1988. Use of superficial edible layer to protect intermediate moisture foods: Application to the protection of tropical fruit dehydrated by osmosis. In: Seow CC (ed) Food
Preservation by Moisture Control, Elsevier Applied Science Publishers Ltd, London, p. 119-219.

[9] Vodjani F, Torres JA, 1990. Potassium sorbate permeability of methylcellulose and hydroxypropyl methylcellulose coatings: Effect of fatty acids, J Food Sci, 55(3): 841846.

[10] Torres JA, Karel M, 1985. Microbial stabilization of intermediate moisture food surfaces, III. Effect of surface preservative concentration and surface $\mathrm{pH}$ control on microbial stability of an intermediate moisture cheese analog, J Food Process Preserv, 9: 107-119.

[11] Ecker JW, Kolbezen MJ, 1977. Influence of formulation and application method on the effectiveness of benzimidazole fungicides for controlling postharvest diseases of citrus fruit, Neth $\mathbf{J}$ Plant Path, 83: 343-352.

[12] Jeon YJ, Kamil JYVA, Shahidi F, 2002. Chitosan as an edible invisible film for quality preservation of herring and Atlantic cod, J Agric Food Chem, 50: 51675178.

[13] Sebti I, Martial-Gros A, Carnet-Pantiez A, Grelier S, Coma V, 2005. Chitosan polymer as bioactive coating and films against aspergillus niger contamination, $\mathrm{J}$ Food Sci, 70(2): 100-104.

[14] Hoagland PD, Parris N, 1996. Chitosan/pectin laminated films, J Agric Food Chem, 44: 1915-1919.

[15] Rodriguez MS, Ramos V, Agulló E, 2003. Antimicrobial action of chitosan against spoilage organisms in precooked pizza, J food Sci, 68(1): 271-274. 
[16] Park SI, Stan SD, Daeschel MA, Zhao $\mathrm{Y}$, 2005. Antifungal coatings on fresh strawberries (Fragaria $\mathrm{X}$ ananassa) to control mold growth during cold storage, $\mathrm{J}$ Food Sci, 70(4): 202-207.

[17] Zivanovic S, Chi S, Draughon AE, 2005. Antimicrobial activity of chitosan films enriched with essential oils, J Food Chem, 70(1): 45-51.

[18] Sathivel S, 2005. Chitosan and protein coatings affect yield, moisture loss, and lipid oxidation of pink salmon (Onchorhynchus gorbuscha) fillets during frozen storage, J Food Sci, 70(8): 455-459.

[19] Rao MS, Chander R, Sharma A, 2005. Development of shelf-stable intermediatemoisture meat products using active edible chitosan coating and irradiation, J Food Sci, 70(7): 325-331.

[20] Juneja VK, Thippareddi H, Bari L, Inatsu Y, Kawamoto S, Friedman M, 2006. Chitosan protects cooked ground beef and turkey against Clostridium perfringens spores during chilling, J Food Sci, 71(6): 236-240.

[21] Nisperos-Carriedo MO, Shaw PE, Baldwin EA, 1990. Changes in volatile flavor components of pineapple orange juice as influenced by the application of lipid and composite films, J Agric Food Chem, 38: 1382-1387.

[22] Debeufort F, Quezada-Gallo JA, Voilley A, 1998. Edible films and coatings: Tomorrow's packaging: A review, Crit Rev Food Sci, 38(4): 299-313.

[23] Martin-Polo M, Voilley A, 1990. Comparative study of the water permeability of edible film composed of arabic gum and glycerol monostearate, Sci Aliments, 10: 473-483.

[24] Greener Donhowe I, Fennema O, 1994. Edible films and coatings: Characteristics, formation, definitions, and testing methods. In: Krochta JM, Baldwin EA, NisperosCarriedo M (eds) Edible Coatings and Films to Improve Food Quality, CRC New York, NY, p. 1-24.

[25] Quezada-Gallo JA, Debeaufort F, Callegarin F, Voilley F, 2000. Lipid hydrophobicity, physical state and distribution effects on the properties of emulsion-based edible films, J Membrane Sci, 180: 37-46.

[26] Hernandez E, 1994. Edible coatings from lipids and resins. In: Krochta JM, Baldwin EA, Nisperos-Carriedo M (eds) Edible Coatings and Films to Improve Food Quality, CRC, New York NY, p. 279-304.

[27] Weiss J, Takhistov P, McClements DJ, 2006. Functional materials in food nanotechnology, J Food Sci, 71(9): 107116.

[28] Zhang C, Ding Y, Ping Q, Yu L, 2006. Novel chitosan-derived nanomaterials and their micelle forming properties, J Agric Food Chem, 54: 8409-8416.

[29] Gennadios A, McHugh TH, Weller CL, Krochta JM, 1994. Edible coatings and films based on proteins. In: Krochta JM, Baldwin EA, Nisperos-Carriedo M (eds) Edible Coatings and Films to Improve Food Quality, CRC New York, NY, p. 201-278.

[30] Karel M, 1990. Encapsulation and controlled release of food additives. In: Schwartzberg HG, Rao MA (eds) Biotechnology and Food Process 
Engineering, Marcel Dekker, New York, NY, p. 277-229.

[31] Chen H, Weiss J, Shahidi F, 2006. Nanotechnology in nutraceuticals and functional foods, Food Technol, 3(6): 3036.

[32] Taylor TM, Davidson PM, Bruce BD, Weiss J, 2005. Liposomal nanocapsules in food science and agriculture, Crit Rev Food Sci Nutr, 45: 1-19.

[33] Gómez-Guillén C, Ihl M, Bifani V, Silva A, Montero P, 2007. Edible films made from Tuna-fish gelatin with antioxidant extracts of two different murta ecotypes leaves (Ugni molinae Turcz), Food Hydrocolloids, 21(7): 1130-1143.

[34] Siripatrawan U, Harte BR, 2010. Physical properties and antioxidant activity of an active film from chitosan incorporated with green tea extract, Food Hydrocolloids, 24(8): 770-775.

[35] Wang L, Dong Y, Men H, Tong J, Zhou J, 2012. Preparation and characterization of active films based on chitosan incorporated tea polyphenols, Food Hydrocolloids, 32(1): 35-41.

[36] Georgantelis D, Blekas G, Katikou P, Ambrosiadis I, Fletouris DJ, 2007. Effect of rosemary extract, chitosan and a-tocopherol on lipid oxidation and colour stability during frozen storage of beef burgers, Meat Science, 75(2): 256-264.

[37] Wang J, Wang B, Jiang W, Zhao Y, 2007. Quality and shelf life of mango (Mangifera Indica L. cv. 'Tainong') coated by using chitosan and polyphenols, Food Science and Technology International, 13(4): 317-322.
[38] Li T, Hu W, Li J, Zhang X, Zhu J, Li $X, 2012$. Coating effects of tea polyphenols and rosemary extract combined with chitosan on the storage quality of large yellow croaker (Pseudosciaena crocea), Food Control, 25(1): 101-106.

[39] Radina PM, Eckert JW, 1988. Evaluation of imazilil efficacy in relation to fungicide formulation and wax formulation. In: Cohen R, Mendel K (eds) Citriculture proceedings of the sixth international citrus congress, Balaban Publishers, Philadelphia PA, p. 1427-1434.

[40] Wells JM, 1971. Heated wax-emulsion with benomyl and 2,6-dichloro-4nitroaniline for control of postharvest decay of peaches and nectarines, Phytopathology, 62: 129-133.

[41] Couey HM, Farias G, 1979. Control of postharvest decay of papaya, Hort Sci, 14(6): 719-721.

[42] Ghaouth AE, Arul J, Ponnampalam R, Boulet M, 1991. Chitosan coating effect on storability and quality fresh strawberries, J Food Sci, 56(6): 1618-1631.

[43] Domenico JA, Rahman AR, Westcott DE, 1972. Effects of fungicides in combination with hot water and wax on the shelf life of tomato fruit, J Food Sci, 37: 957-960.

[44] Tay SL, Perera CO, 2004. Effect of 1methylcyclopropene treatment and edible coatings on the quality of minimally processed lettuce, J Food Sci, 69(2): 131135.

[45] Carlin F, Gontard N, Reich M, Nguyen-The C, 2001. Utilization of zein coating and sorbic acid to reduce Listeria 
monocytogenes growth on cooked sweet corn, J Food Sci, 66(9): 1385-1389.

[46] Quezada-Gallo JA, Diaz-Amaro R, Gramin A, Pattyn C, Debeaufort F, Voilley A, 2004. Biopolymers used as edible coating to limit water transfert, colour degradation and aroma lost in Mexican fruits, Acta Horticulturae, 682: 1709-1716.

[47] Quezada-Gallo JA, Bon Rosas F, Ramírez Gómez M, Díaz Amaro MR, Noah N, d Datzenko A, 2005. Performances of edible coatings combined with bread additives to preserve fried donuts and mexican white bread "bolillo", Proceedings of the annual meeting of the institute of food technologists, 20-25 June, New Orleans, LA.

[48] Guilbert S, 1986. Technology and application of edible protective films. In: Mathlouthi M (ed) Food Packaging and Preservation: Theory and Practice. Elsevier Applied Sciece Publishing Co, London, p. 371-394.

[49] Katz EE, Labuza TP, 1981. Effect of water activity on the sensory crispness and mechanical deformation of snack food products, J Food Sci, 46: 403.

[50] Rico-Peña DC, Torres JA, 1990. Edible methylcellulose-based films as moisture-impermeable barriers in sundae ice cream cones, J Food Sci, 55: 1468-1469.

[51] Greener I, Fennema O, 1989. Evaluation of edible bilayer films for use as moisture barriers for food, J Food Sci, 54(6): 1400-1406.

[52] Baranowski ES, 1990. Miscellaneous food additives. In: Branen AL, Davidson
PM, Salminen S (eds) Food Additives, Marcel Dekker, New York, NY, p. 511-578.

[53] Chung D, Papadakis SE, Yam KL, 2003. Evaluation of a polymer coating containing triclosan as the antimicrobial layer for packaging materials, Int J Food Sci Tech, 38: 165-169.

[54] Janes ME, Kooshesh S, Johnson MG, 2002. Control of on the surface of Listeria monocytogenes refrigerated, ready-to-eat chicken coated with edible zein film coatings containing nisin and/ or calcium propionate, J Food Sci, 67(7): 2754-2757.

[55] Longinos-Martinez S, MendozaChapulin MR, Quezada-Gallo JA, PedrozaIslas R, 2005. Películas antimicrobianas para carne y productos cárnicos, Mundo lácteo y cárnico, 5(6): 12-17.

[56] Coma V, Martial-Gros A, Garreau S, Copinet A, Salin F, Deschamps A, 2002. Edible antimicrobial films based on chitosan matrix, J Food Sci, 67(3): 1162116.

[57] Çağrı A, Üstunol Z, Osburn W, Ryser ET, 2003. Inhibition of Listeria monocytogenes on hot dogs using antimicrobial whey protein-based edible casing, J Food Sci, 68(1): 291-299.

[58] Lee SY, Krochta JM, 2002. Accelerated shelf life testing of wheyprotein-coated peanuts analyzed by static headspace gas chromatography, J Agric Food Chem, 50: 2022-2028.

[59] Appendini P Hotchkiss JH, 2002. Review of antimicrobial food packaging, Innov Food Sci Emerging Tec, 3: 113-126.

[60] Duncan TV, 2011. Applications of nanotechnology in food packaging and food 
safety: barrier materials, antimicrobials and sensors, J Colloid Interf Sci, 363: 1-24.

[61] Cushen M, Kerry J, Morris M, CruzRomero M, Cummins E, 2012. Nanotechnologies in the food industryrecent developments, risks and regulation, Trend Food Sci Tec, 24: 30-46.

[62] Coles D, Frewer LJ, 2013. Nanotechnology applied to European food production-a review of ethical and regulatory issues, Trend Food Sci Tec, 34: 32-43.

[63] Sung S, Sin LT, Tee T, Bee S, Rahmat AR, Rahman WAWA, Tan A, Vikhraman M, 2013. Antimicrobial agents for food packaging applications, Trends Food Sci Tec, 33: 110-123.

[64] López-Carballo G, Gómez-Estaca CR, Hernández-Muñoz GR， 2012. Active antimicrobial food and beverage packaging. In: Yam KL, Lee DS, editors. Emerging Food Packaging Technologies: Principles and Practice. Cambridge (UK): Woodhead Publishing, 27-51.

[65] Otoni CG, Espitia PJP, AvenaBustillos RJ, McHugh TH, 2016. Trends in antimicrobial food packaging systems: Emitting sachets and absorbent pads, Food Research International, 83: 60-73.

[66] Var I, Uzunlu S, 2018. Introductory Chapter: Active Antimicrobial Food Packaging, In Active Antimicrobial Food Packaging, IntechOpen, 1-3.

[67] Eswaranandam S, Hettiarachchy N, Meullenet J, 2006. Effect of malic and lactic acidincorporated soy protein coatings on the sensory attributes of whole apple and fresh-cutcantaloupe, Journal of Food Science, 71(3): 307-313.

[68] Sanders ES, 1999. Probiotics. Food Technolog, 53(11): 67-77.

[69] Sanders ES, Huis in't Veld J, 1999. Bringing a probiotic containing functional food to the market: Microbiological, product, regulatory and labeling issues, Antonie van Leeuwenhoek, 76: 293-315.

[70] De Prisco A, Mauriello G, 2016. Probiotication of foods: A focus on microencapsulation tool, Trends Food Sci. Technol, 48: 27-39.

[71] Espitia PJP, Batista RA, Azeredo HMC, Otoni CG, 2016. Probiotics and their potential application in active edible films and coatings, Food Res Int, 90: 42-52.

[72] Mei Y, Zhao Y, 2003. Barrie rand mechanical properties of milk protein-based films containing nutraceuticals, J Agric Fodd Chem, 51: 1914-1918.

[73] Miller KS, Krochta JM, 1997. Oxygen and aroma barrier properties of edible films: A review, Trends Food Sci Tecnol, 8: 228237.

[74] Quezada-Gallo JA, Debeaufort F, Voilley A, 1999. Interactions between aroma and edible films, 1 . Permeability of methylcellulose and low-density polyethylene films to methyl ketones, J Agric Food Chem, 47: 108-113.

[75] Amanatidou A, Slump RA, Gorris LGM, Smid EJ, 2000. High oxygen and high carbon dioxide modified atmospheres for shelf-life extension of minimally processed carrots, J Food Sci, 65(1): 61-66. 